\title{
Towards a Cooperative Approach to Hobby Metal Detecting : The European Public Finds Recording Network (EPFRN) Vision Statement
}

\section{Dobat, Andres}

2020-05-05

Dobat , A , Deckers , P , Heeren , S , Lewis , M , Thomas , S E \& Wessman , A P F 2020 , '

Towards a Cooperative Approach to Hobby Metal Detecting : The European Public Finds

Recording Network (EPFRN) Vision Statement ' , European Journal of Archaeology , vol. 23 , no. 2 , 1461957120000017 , pp. 272-292 . https://doi.org/10.1017/eaa.2020.1

http://hdl.handle.net/10138/314835

https://doi.org/10.1017/eaa.2020.1

acceptedVersion

Downloaded from Helda, University of Helsinki institutional repository.

This is an electronic reprint of the original article.

This reprint may differ from the original in pagination and typographic detail.

Please cite the original version. 


\title{
European Journal of Archaeology 2020 EAA/European Association of Archaeologists
}

Citation of original paper: Dobat, A., Deckers, P., Heeren, S., Lewis, M., Thomas, S., \& Wessman, A. (n.d.). Towards a Cooperative Approach to Hobby Metal Detecting: The European Public Finds Recording Network (EPFRN) Vision Statement. European Journal of Archaeology, 1-21.

doi:10.1017/eaa.2020.1

\section{Towards a Cooperative Approach to Hobby Metal Detect- ing: The European Public Finds Recording Network (EPFRN) Vision Statement}

\author{
Andres Siegfried Dobat ${ }^{1}$, Pieterjan DeCKers ${ }^{2}$, Stijn HeEren ${ }^{3}$, Michael LeWiS ${ }^{4}$, Suzie Thomas ${ }^{5}$ AND \\ ANNA WeSSMan6
}

Hobby metal detecting is a controversial subject. Legal and policy approaches differ widely across national and regional contexts, and the attitudes of archaeologists and heritage professionals towards detectorists are often polarized and based on ethical or emotive arguments. We, the European Public Finds Recording Network (EPFRN), have implemented collaborative approaches towards detectorist communities in our respective contexts (Denmark, England and Wales, Finland, Flanders and the Netherlands). Although our motivations are affected by our national circumstances, we base our work on an agreed set of goals, practices, and visions. This article presents the EPFRN's vision statement and provides insight into its underlying thoughts. We hope to create a debate on how to develop best practice approaches that acknowledge the inherent challenges of hobby metal detecting while realizing its potential.

Keywords: heritage protection, metal detecting, finds, digital archaeology, historic environment, crowdsourcing, citizen science

\section{INTRODUCTION}

Hobby metal detecting for archaeological objects is a contentious issue, not least in Europe. Especially since the 1990s, the activity has increased in popularity, and there is little prospect of this reversing. On the contrary, it is more likely that its increasing profile, through the press and social media, will increase the current 'metal detector boom' experienced in many countries in future.
The opinions and attitudes of archaeologists towards (and against) hobby metal detecting are often polarized, while legal and policy approaches differ greatly across jurisdictions, ranging from highly restrictive to liberal or even supportive, and many nuances in between. Like metal detecting itself, they are highly internal to the different European countries or regions and legislations (Bland,

\footnotetext{
${ }^{1}$ School of Culture and Society, University of Aarhus, Denmark,farkado@cas.au.dk

${ }^{2}$ School of Culture and Society, University of Aarhus, Denmark, pdeckers@cas.au.dk

${ }^{3}$ Faculty of Humanities, Vrije Universiteit Amsterdam,The Netherlands, s.heeren@vu.nl

${ }^{4}$ Portable Antiquities Scheme, The British Museum, London, UK, MLewis@britishmuseum.org

${ }^{5}$ Department of Cultures, University of Helsinki,Finland,Thomas, suzie.e.thomas@helsinki.fi

${ }^{6}$ Department of Cultures, University of Helsinki, Finland,Wessman, anna.wessman@helsinki.fi
} 
2005; Scheschkewitz, 2013; Makowska et al., 2016; Deckers, 2019).

Controlling hobby metal detecting may be a justified policy choice in some contexts. Far too numerous are the examples of heritage sites from all periods across Europe which have been plundered by illegal or irresponsible detectorists in search of artefacts for their own personal collections or for sale (Lecroere, 2016; Ganciu, 2018), or even in ignorance. To protect sites from illegal detecting, the Valletta Convention on the Protection of the Archaeological Heritage (Valletta, 1992: article 3,iii) recommends that member states control the use of metal detectors by non-professionals by making it subject to prior authorisation (by the official heritage sector). Intriguingly, the national responses to that injunction have been diverse.

Over the past years, the heritage sectors in many European countries have poured significant resources into the enforcement of legal restrictions against hobby detecting, and into raising awareness of the problems relating to illegal metal detecting, not least among representatives of the law enforcement authorities. Despite these efforts, the effectiveness of a ban on or severe restriction of hobby metal detecting to safeguard cultural heritage can be questioned. The enforcement of heritage legislation remains a matter of low priority, especially under the current political climate of cutbacks to enforcement agencies. Furthermore, while the media in countries with restrictive policies highlight the few convictions of 'treasure hunters' caught in the act, many other detectorists continue practising metal detecting without being prosecuted (e.g. Huth, 2013: 134; Karl \& Möller, 2016; Gundersen et al., 2016; Ulst 2010). Here we argue that illegal and irresponsible metal detecting cannot be policed effectively by legislation alone. Indeed, restrictive legislation might just offer a comforting illusion that cultural heritage is being protected, while thousands of finds are retrieved by detectorists (and probably others) without the prospect of ever being recorded.

This dilemma has led to a tacit acceptance of illegal hobby metal detecting in many contexts. In others, it has prompted pragmatic approaches, trying to make the best of this situation. In dealing with the phenomenon of hobby metal detecting in our respective legal and cultural contexts, we, the authors and members of the the European Public Finds Recording Network (EPFRN hereafter), have taken a step beyond pragmatism through adopting a cooperative approach towards the detectorist communities. It emphasises cooperation and participation and aims to realize the potential of hobby metal detecting for the benefit of archaeological research.

We have found common ground in a set of guiding objectives and visions, under the heading of the EPFRN's vision statement (see below). With this article, we introduce our views and provide insights into its founding thoughts and principles. This leads to an argument in favour of a liberal policy choice and a cooperative approach, which we have found to be the most productive response to the metal detecting phenomenon, at least in our respective national and regional contexts. We hope to stimulate what we consider a necessary debate about how European archaeology can develop more constructive approaches towards hobby metal detecting.

\section{IMPLEMENTING A CoOperative Approach: The EPFRN RECORDING SCHEMES}

Cooperation between the heritage sector and hobby detectorists is not new, nor is it exclusive to the contexts presented in this article. Similar approaches, devised to include responsible detectorists in research projects or other controlled activities, are increasingly being endorsed elsewhere, even in countries where hobby detecting is otherwise controlled or even prohibited (Majchczack, 2016; Rácz, 2017; Komoróczy et al., 2017; Ganciu, 2018; Günther, 2019).

We who endorse the EPFRN's vision statement all work under regimes of heritage protection that permit metal-detecting in most circumstances, thus necessitating engagement with that community. Although we are based in different national contexts, we all are rooted in Western/Northern European cultural heritage management traditions and attitudes towards public inclusion and cooperation. However, values and attitudes towards heritage among the public and detectorists as well as the wider social and cultural preconditions for engaging metal detector communities may differ significantly across Europe.

A unique aspect of our approach has been the development and provision of online digital schemes facilitating the recording of metaldetected and other non-professionally-discovered finds; it involves both non-professionals and professionals and makes these finds accessible to all. All the schemes listed in Table 1 have either been initiated or are currently directed by members of the EPFRN 


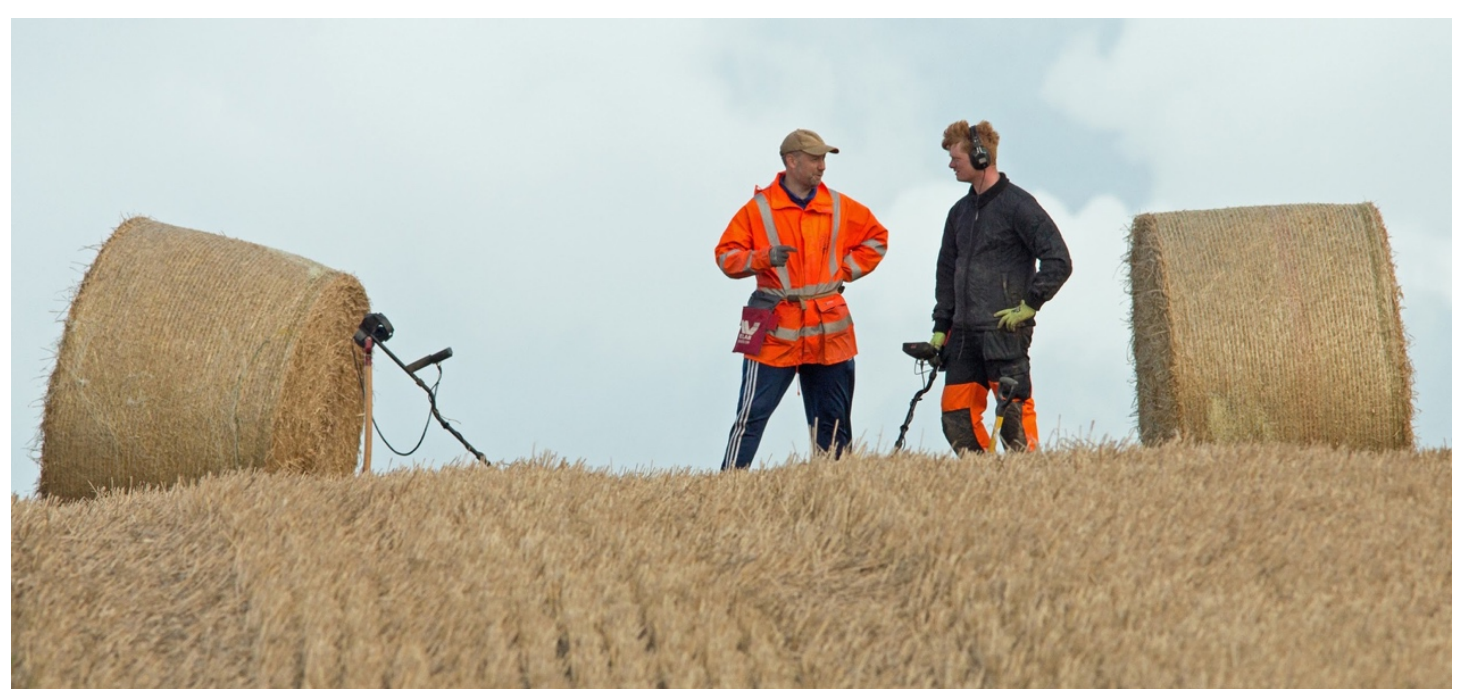

Figure 1. Metal detector users in a permissive context (Denmark 2015), operating in open and in-tensely cultivated landscapes. Photograph: Allan Faurskov.

(for more information, see https://www.helsinki.fi/en/networks/european-public-

finds-recording-network)

There are marked differences in legislation and attitudes towards metal-detecting in England, Wales, Flanders, The Netherlands, Denmark, and Finland. The national schemes function differently and are characterized by varying degrees of user inclusion in the recording process. They also have very different histories. The Portable Antiquities Scheme (PAS) for example was established as early as 1997. Others are comparably young or still in development. Similarly, while, for example, the Portable Antiquities of the Netherlands (PAN) scheme functions within a legal system that grants ownership rights over cultural property to individuals, many historically significant finds recorded in the Danish Digitale Metaldetektorfund (DIME) scheme are considered property of the state. A discussion of these recording schemes' background and impact, however, cannot be undertaken here and we refer to Table 1 where a detailed introduction to the individual schemes via links and references is given.

What the schemes have in common is their operational aim: to provide a portal for digital recording and, hence, digital preservation of metal detector (and other public) finds. More specifically, all the schemes share the following elements:

- making finds and contextual data accessible to the general public and for research;

- applying the principle of 'user engagement' and crowdsourcing, in order to implement the ambitions of the Faro Convention (Faro, 2005);
- promoting the idea that human values should be at the centre of cultural heritage and that all people should be able to participate in all aspects of cultural heritage management.

The schemes are technological solutions using a digital recording process, which has become increasingly relevant in the wake of the digital revolution and the rise of 'big data'. This has led to an increased emphasis on finds data instead of physical objects. In England and Denmark, for example, metal detector finds cannot now be ignored by those engaged in serious archaeological research. The schemes also fulfil an important social function by facilitating public inclusion and participation in the archaeological process. Beyond this, they act as communication platforms, informing and educating users on various aspects of archaeological practice and the treatment of objects (Portable Antiquities Advisory Group, 2017; Portable Antiquities of the Netherlands, 2019).

More recently, the EPFRN and individual members of the network have joined the EU Framework Programme HORIZON 2020funded ARIADNEplus partnership (Ariadne, 2019), which aims to integrate the contents of our respective schemes into the ARIADNEplus research infrastructure to facilitate research and other possible uses of the data across modern national boundaries.

\section{Metal Detector Complexities}

For us, hobby metal detecting covers metal detecting outside a controlled archaeological excavation, primarily in pursuit of leisure (see Ferguson, 2013 who describes the 
hobby as 'serious leisure' in reference to Stebbins, 1992). Assessing the scale and nature of hobby detecting on national or regional levels, and documenting developments over time, have proved to be complex matters. Netnographic studies, focusing on social media, have been shown to result in heavily biased and unreliable absolute numbers (Hardy, 2017), beyond indicating that legal regimes seem to have little impact on the number of active detector users in a given context (Karl \& Möller, 2016). Estimates for specific countries can be drawn from a variety of sources (e.g. Thomas, 2012; Hardy, 2017; Immonen \& Kinnunen, 2017; Dobat et al., 2019a). What is beyond doubt is that hobby detecting will remain an important issue in all European countries, in both liberal and restrictive contexts. Perhaps more worrying is the lack of reliable data on the scale and the impact of detecting that, in many countries, has seriously hampered the formulation of appropriate responses. Metal detectorists are only one of many groups with a legitimate interest in archaeology, but the growing community of detectorists has a profound and direct impact on archaeological heritage, as it is they who are making most archaeological discoveries outside a controlled environment.

Detectorist motivation constitutes a second factor, after scale. An important element of the polarized debates on detecting among heritage professionals is the simplistic dichotomy between 'good' and 'bad' detectorists. The 'good' practitioners are assumed to be driven by a desire to contribute to the scientific process of writing local or national history and striving towards professional recognition of their findings, whereas the 'bad' ones are scorned as mere 'treasure hunters', or worse, looters. Both types exist, but detectorists are a very heterogeneous group, with many somewhere in between these extremes (see e.g. Thomas, 2016).

Indubitably, some detectorists, including in the contexts in which we find ourselves working, are primarily driven by financial motivations or the desire to build private collections. Possibly, some of these detectorists have no or little interest in cooperating with the professional heritage sector or in following the various codes of practice for responsible metal detecting (see e.g. Meller, 2004; Gill, 2010; Rodríguez Temiño \& Roma Valdés, $2015)$. For others, however, the primary motivation appears to be the desire simply to hold a piece of tangible history and engage with the past in a first-hand, active fashion.
For some, detecting is just another physical activity in the great outdoors, and others are attracted by the social contacts the hobby affords. Finally, there are those for whom detecting is more of a personal project, fulfilling a need to 'get out of the house' and find some mental relaxation (e.g. Thomas et al., 2015; Immonen \& Kinnunen, 2017; Winkley 2016; Dobat et al. 2019b; Wessman, forthcoming). In whatever way one hopes to engage with metal detecting, it is crucial to understand the nuances of these motivations. Detectorists across Europe are influenced by their respective national, cultural, and social contexts; their activities are shaped by the nature of the landscape, the archaeological record and heritage policy, as well as by their socio-economic backgrounds and community identities. Recognizing this multitude of contributing factors is an important prerequisite for engaging with detectorists and a necessary step in the development of appropriate policies.

Impact constitutes our third partial unknown. Here too the debate is muddled by binary oppositions that obscure all nuance: liberal/restrictive, licit/illicit, responsible/irresponsible. We argue that these hamper discussions about the potential contribution or threat of hobby detecting. A restrictive legislation precludes the possibility of detecting in (what the EPFRN might consider) a responsible manner, and may result in more, rather than less, illicit activity, particularly if it remains unenforced. Conversely, even the most liberal policies in Europe do not allow detecting in all locations and under all circumstances. More useful from our perspective, especially when it comes to developing a best practice policy and recommendations, is an identification of destructive and constructive practices and behaviours among detecting communities. Exchanging information about these practices is of equal importance: detecting communities are not necessarily aware of the basic rules of best archaeological practice, so proper communication of preferred practices is key in any future approach to the phenomenon. This is only possible when archaeologists reach out to detectorists and the public at large.

\section{EXPLAINING THE VISION}

\section{Knowledge gain}

In countries with a long tradition of liberal policies (such as Denmark or England), accumulated data on detector finds have long demonstrated their potential as sources of in 


\begin{tabular}{|c|c|c|c|}
\hline Name & Region & $\begin{array}{l}\text { Institutional an- } \\
\text { chorage }\end{array}$ & Link \\
\hline $\begin{array}{l}\text { Portable Antiquities } \\
\text { Scheme (PAS) } \\
\begin{array}{l}\text { (9) } \\
\text { Portable } \\
\text { Antiquities } \\
\text { Scheme } \\
\text { www.finds.org.uk }\end{array}\end{array}$ & $\begin{array}{l}\text { England and } \\
\text { Wales }\end{array}$ & $\begin{array}{l}\text { British Museum and } \\
\text { National Museum } \\
\text { Wales }\end{array}$ & $\begin{array}{l}\frac{\text { https://finds.org.uk/ }}{\text { https://museum.wales/port- }} \\
\text { able-antiquities-scheme-in- } \\
\text { wales/ } \\
\text { see Lewis, } 2016\end{array}$ \\
\hline MEDEA & Flanders & $\begin{array}{l}\text { Free University } \\
\text { Brussels/Histories } \\
\text { vzw }\end{array}$ & $\begin{array}{l}\underline{\text { https://vondsten.be/ }} \\
\text { see Deckers et al., } 2016\end{array}$ \\
\hline $\begin{array}{l}\text { Portable Antiquities of } \\
\text { the Netherlands (PAN) }\end{array}$ & The Netherlands & $\begin{array}{l}\text { Vrije Universiteit } \\
\text { Amsterdam }\end{array}$ & $\begin{array}{l}\text { https://www.portable-antiq- } \\
\text { uities.nl/ } \\
\text { see Kars \& Heeren, } 2018\end{array}$ \\
\hline $\begin{array}{l}\text { DIME: Digitale Metal- } \\
\text { detektorfund }\end{array}$ & Denmark & Aarhus University & $\begin{array}{l}\text { https://dime.au.dk/ } \\
\text { see Dobat et al., 2019a }\end{array}$ \\
\hline $\begin{array}{l}\text { SuALT: The Finnish Ar- } \\
\text { chaeological Finds Re- } \\
\text { cording Linked Open Da- } \\
\text { tabase (Löytösampo/ } \\
\text { FindSampo) } \\
\end{array}$ & Finland & $\begin{array}{l}\text { University of Hel- } \\
\text { sinki, Aalto Univer- } \\
\text { sity and Finnish } \\
\text { Heritage Agency }\end{array}$ & $\begin{array}{l}\text { Under development } \\
\text { see: } \underline{\text { https://blogs.hel- }} \\
\text { sinki.fi/sualt-project/ } \\
\text { see Wessman et al., } 2019\end{array}$ \\
\hline
\end{tabular}

Table 1. Overview of the finds recording schemes constituting the EPFRN and their context and background. For more detailed introduction to the individual schemes follow the links or view references.

formation on various aspects of past societies. For some fields of research, the evidence of hobby metal detector finds made available for research has radically altered traditional views and led to entirely new pictures of the past; examples include supra-regional networks of production and exchange, settlement landscapes, or more abstract concepts, such as identity, gender, and religion (see e.g. Worrell et al., 2010; Deckers, 2012; Dobat, 2013; Oksanen \& Lewis, 2015).

Metal detector finds were once (and in some contexts still are) argued to be of limited scientific value, compared to 'proper' archaeological finds, due to a lack of contextual information. The lack of a narrowly defined context does impose certain limits and requires a special analytical approach compared to excavated material. Work on the PAS dataset in particular has led to a thorough understanding of the various biases affecting the distribution of detector finds (Robbins, 2013; Oksanen \& Lewis, 2015). In addition, a growing body of scholarly work demonstrates that detector find assemblages (like surface finds recovered during fieldwalking) also constitute meaningful archaeological signatures (e.g. Heeren \& Van der Feijst, 2017; Hadley \& Richards, 2018; Christiansen, 2019). Even though detector finds from plough horizons cannot normally be related to specific features, their spatial distribution adds information about the character of a site as well as excavated features and structures (e.g. Petersen, 1994; Jørgensen, 2000). Archaeological finds come from different types of contexts and contribute differently to our understanding of the past. Metal detector finds must be treated on their own terms in order to get the most out of the data available (for a critical perspective on the use of detector finds as research data, see Robbins, 2013; Cooper \& Green 2017).

If detector finds are to be analysed as scientific data, they need to be reported, recorded, and made accessible. At an early point in the popularity of metal detecting, in the 1980s and 1990s, the heritage sectors in Denmark, England, and Wales understood that it was important to cooperate with finders to secure 


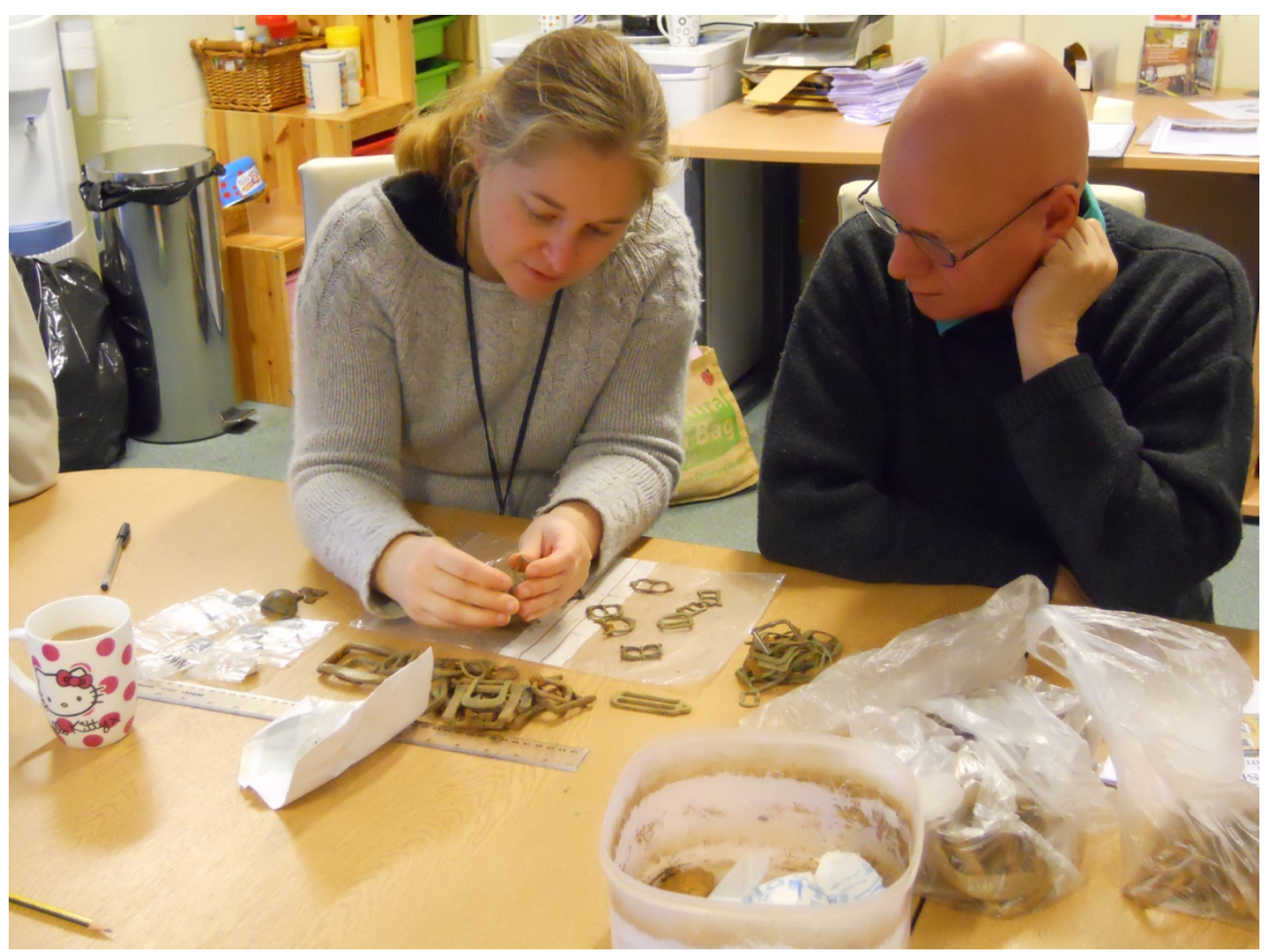

Figure 2. The recording of finds through the PAS for England and Wales is based on a regional network of finds liaison officers (FLOs) establishing trustful relationships with finders. Here Laura

Burnett (Somerset FLO) is examining a detector user's finds. Photograph: courtesy of the PAS.

information about these finds, if they are to be exploited in research. In these countries, the data compiled over the past few decades-through the collection policy of Danish museums and the Danefæ (treasure trove) administration underlying it, and the Portable Antiquities Scheme in England and Wales-have provided a basis for countless research projects. The PAS alone has contributed substantially to more than $130 \mathrm{PhD}$ projects and 170 Masters dissertations (https://finds.org.uk/research).

We contend that the systematic recording and study of metal-detected objects under a cooperative scheme yields a greater gain in knowledge about the past than is possible under a restrictive scheme. By contrast, in most restrictive contexts, detector finds are largely unreported and information about them is, therefore, difficult to access and interpret (see for example Hardy, 2017; Deckers et al., 2018). The mistrust between professional archaeologists and hobby detectorists, often a consequence of restrictive legislation and disapproving attitudes, further obscures the availability of reliable metal-detected finds data. Moreover, the deontological limits set by the professional sector on using metal-detecting data contribute to this trust gap as well as limit progress even further.

It could be argued that we cannot evaluate the advantages of a liberal system in terms of knowledge gain as long as we are unable to estimate the loss of potential research data in the form of unreported finds. However, as mentioned, metal detecting is taking place on a vast scale under restrictive legal regimes (Karl \& Möller, 2016; Hardy, 2017). Spectacular discoveries made by people caught illegally searching merely gives us a glimpse of the enormous research potential that is being lost (e.g. Meller, 2004; Lecroere, 2016). The vast majority of illegal detectorists in these contexts remain unnoticed and their finds remain unreported, and hence never enter the archaeological record. Considering the difficulty of curtailing hobby metal detecting through restrictive legislation, it is surely better to have reports on a representative fraction of metal-detected finds than to have none at all. 


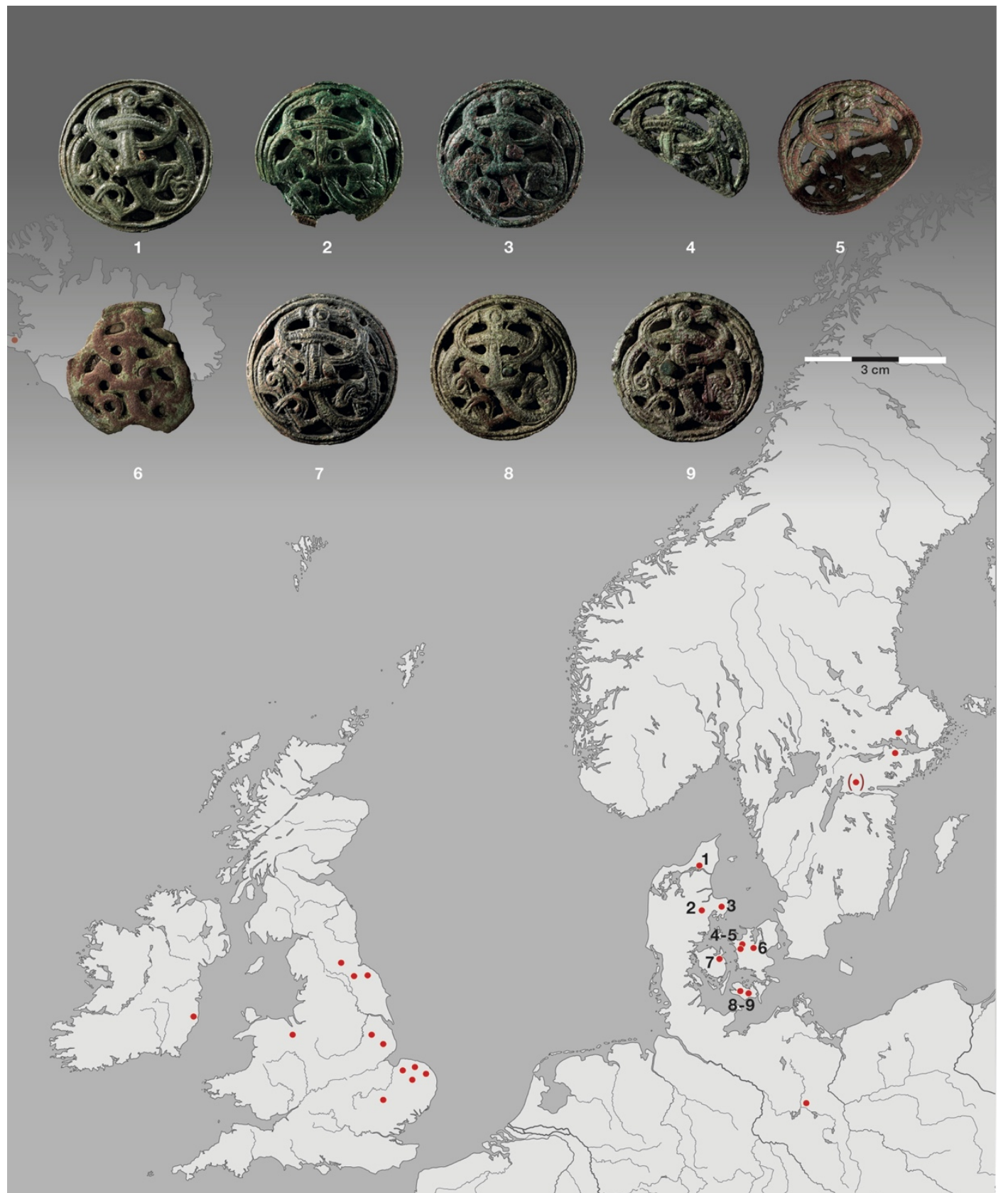

Figure 3. Cultural connections across the North Sea and modern national boundaries as reflected

in the distribution of Viking Age composite disc brooches with Jelling style ornamentation

(Jeppesen, 2011). Maps like these would be impossible to create without the permissive approaches towards hobby metal detecting and finds recording practices in England and Denmark. Image: Louise Hilmar.

\section{Preservation issues}

Since the Valletta Convention (1992), the principle of 'preservation in situ' whenever possible, is a central tenet of European heritage protection legislation. While a hallmark of the heritage preservation discourse (Patiwael et al., 2019: 336), it stands in sharp contrast to the stereotypical public perception of archaeology as the 'search for things'. As heritage professionals, we know this popular image to be a distorted simplification, yet for many, particularly detectorists, the thrill and fascination of discovering a tangible piece of the past is what makes the very essence of archaeology (e.g. Holtorf, 2005; Perry, 2019). Many simply do not understand the principle of 'preservation in situ' and do not appreciate archaeologists' sensitivity about people excavating and finding ancient remains since they believe the task of the archaeologists is to 'dig and find stuff' and transfer their discoveries to museums, where such things 'belong' (e.g. Ferguson, 2016). For the detecting community (and perhaps others too), 'preservation 
in situ' can be interpreted as a means of monopolizing archaeology and preventing nonprofessionals from gaining direct access. It is therefore important for archaeologists to be aware that different values, interpretations, and meanings are given to the archaeological heritage beyond the analytical lenses through which archaeologists attempt to make sense of the material past. If we want the wider public to be interested and involved in learning about and understanding the past (which surely we must, especially as many of us work in public museums, universities, or the heritage sector more generally, which are principally funded through public taxation), we must find ways or reaching out beyond those already involved and better explain our methods for preserving that past.

The EPFRN supports the ideal of 'preservation in situ' of the archaeological record whenever possible. Known monuments and sites with finds in intact contexts should only be excavated with a clear research agenda; in these cases, searching recognized, protected archaeological sites simply to find artefacts is completely unacceptable. In other circumstances, however, especially with respect to metal detector finds, in situ preservation is not always the best possible choice. Longterm studies on copper alloy objects in ploughsoil have demonstrated the damaging effect of the increasing use of chemical fertilisers and soil acidification caused by acidic emissions (Tronner et al., 1995; Nord \& Lagerlöf, 2002). As copper alloy is the most frequent material category among metal detector finds from north-western Europe, the damage thus caused to the archaeological heritage is immense, and the long-term consequences are difficult to assess. Agricultural soil treatment (ploughing, etc.) with increasingly effective devices has shown to result in the mechanical destruction of finds buried in the ploughsoil (Haldenby \& Richards, 2010; Svensson, 2014).

The damaging effect of archaeological objects being extracted from their original contexts constitutes a valid argument against liberal policies towards metal detecting. This is undoubtedly true in many cases, when detectorists deliberately or inadvertently target known historical sites and/or irrevocably destroy structures and other archaeological features to recover finds, whether these sites are known or not. There are even cases where detectorists realized that a find was in a stratified context and still removed it without ar- chaeological support, perhaps in the excitement of discovery or fearing that, if left, others might claim it (e.g. Ferguson, 2016: 12324). In reality, however, most detector finds from north-western European countries are likely to originate from the ploughsoils. In Denmark, for example, only a small minority of 485 finds (1.6 per cent) of the total amount of 30,224 finds recorded in the DIME scheme up to July 2019 were found in the context of possibly undisturbed landscapes. Likewise, of the 79,353 finds logged with the PAS in 2017, 93 per cent came from cultivated land; just over 2 per cent from grassland, and 2 per cent from the foreshore (Lewis, 2018). Normally, any contextual associations of an object in the soil have been compromised by the mixing effect of ploughing and other agricultural processes. Under such circumstances, the recovery of the object in itself has no damaging effect, as long as its position is logged with the finds record.

In the open and intensely cultivated landscapes of Europe, not only are the metal finds in the ploughsoil in danger of getting lost, but the remaining features below the plough's reach are also at risk. These can only be monitored and rescued if known. In this light, the contribution of metal detecting goes beyond the artefacts themselves. In some regions of Denmark and England, the bulk of detector find spots represent newly discovered historical environments, i.e. sites which the official heritage agencies would not be able to include in their regional heritage monitoring and protection plans, were it not for their discovery by detectorists (Daubney, 2016; Feveile, 2016).

Following these arguments, we might consider hobby metal detecting an effective tool for cultural heritage management and protection, in full accordance with the overarching goals of heritage protection, that is to safeguard and preserve in situ whenever possible. Whether archaeologists (and others) make the best use of the data to protect the past, and whether (or not) most hobbyist detectorists would be happy to relinquish the right to detect an important landscape, if it was taken out of cultivation for example, are questions for debate. In any case, for detector finds that are currently threatened by increasing deterioration in open and cultivated landscapes, their extraction from the ploughsoil might be the best option for the find to be recorded, preserved, and made accessible. 


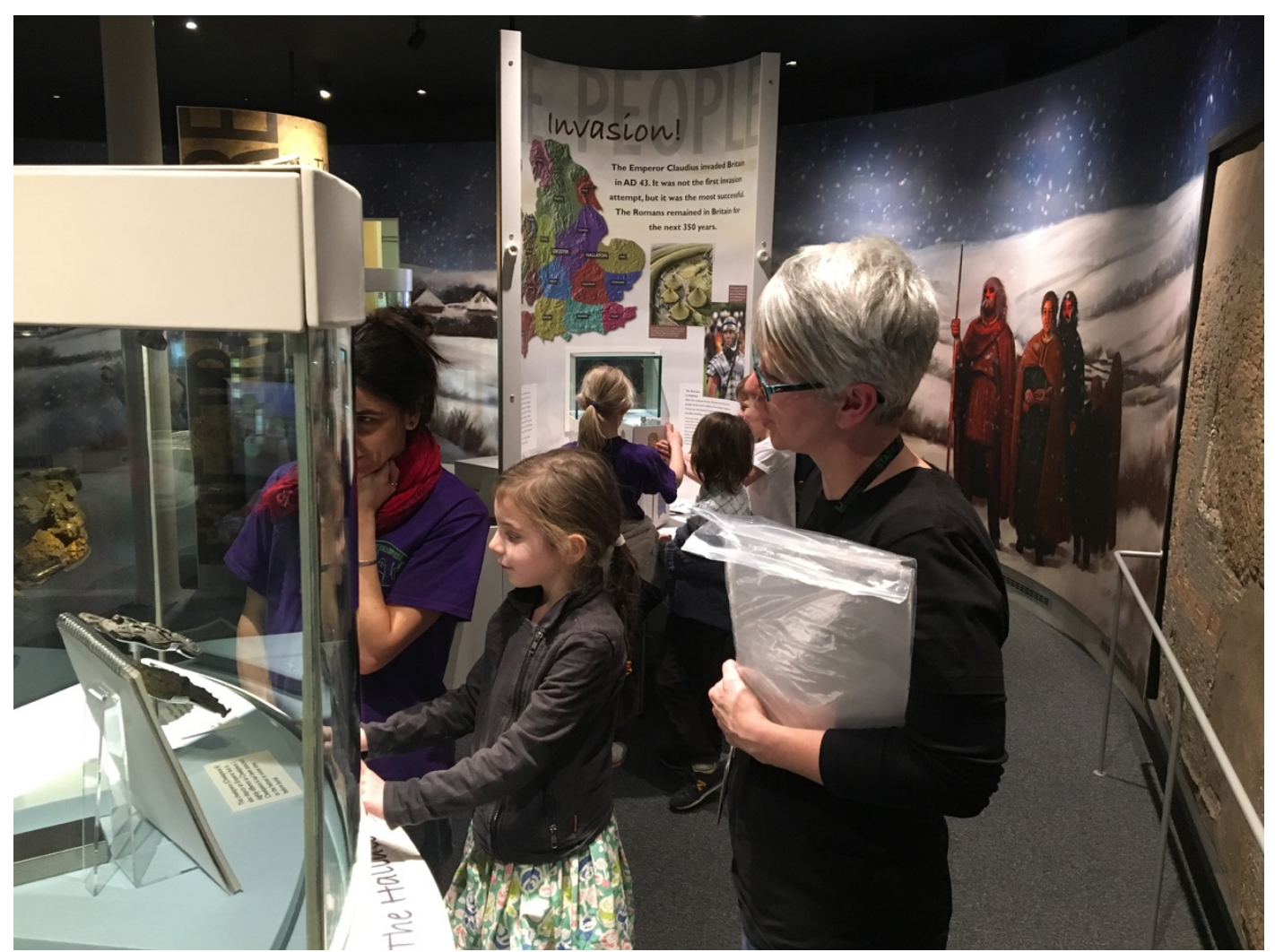

Figure 4. Members of the Leicestershire Young Archaeologists' Club visiting the special exhibit of the Roman-period Hallaton Treasure at Harborough Museum, with Wendy Scott (Leicestershire \& Ru land FLO). Photograph: courtesy of the PAS.

\section{Social and ethical aspects}

European societies have seen radical changes over the past decades, not least because of a growing focus on the ideals of social multivocality, inclusion, and participation. Though still an important cornerstone of archaeological outreach, the sole presentation of archaeological expert knowledge on site, in the context of museums, or through the media is (or will be) at variance with the expectations of contemporary society. Today's audiences have become acquainted with the idea of having the right to be included and to participate actively in the archaeological process (Kajda et al., 2018; Perry \& Beale 2015).

Heritage professionals and even policy makers increasingly recognize this new reality of archaeological outreach, most prominently with the Faro Convention, which promotes the idea that parties should 'encourage everyone to participate in the process of identification, study, interpretation, protection, conservation and presentation of the cultural heritage'(Faro, 2005, Article 12: Access to cultural heritage and democratic participation). Constituting one of the inspirational sources of the Faro convention, participatory rights within the domains of culture and science are even enshrined as a universal human right in article 27 (1) of the United Nations Universal Declaration of Human Rights (UN, 2019).

Against this expectation of inclusiveness, archaeology in many countries has seen a distinct process of professionalization since the Valletta Treaty of 1992. Although this had many positive effects, it has also resulted in creating a gap between professionals and non-professionals, with the latter increasingly excluded from doing archaeology, and the former finding it harder to include the public (see for example Fahlander, 2017; Perring \& Orange 2017).

The growing popularity of hobby metal detecting is also a consequence of the current Zeitgeist. Much of its appeal lies in the fact that metal detecting allows practitioners to act creatively as producers of their own local and personal histories, in contrast to being passive consumers of expert archaeologists' narratives. Studies of the motivations of detectorists (Thomas, 2012; Winkley, 2016; Dobat et al., 2019b; Wessman, forthcoming) 
show that many are driven by a desire to enter into a personal and hands-on dialogue with the past and hold or even own a piece of history. Their finds give them a direct connection to the past and allow them to connect intimately with 'their' heritage and history. Importantly, they can make this connection independently, without expert facilitation, or educational, cultural, or social preconditions. This may of course not be the motivation for all hobby detectorists but, based on our personal experiences of meeting and working with detectorists, it is clear that many have a particular interest in the past landscapes that they search.

Within academia the social trends noted above have been assimilated under the banner of crowdsourcing and citizen science, and the participation of large communities of non-professionals in scientific processes. Public Participation in Scientific Research (PPSR) has become increasingly relevant over the past decades in varying academic disciplines, not only as a means of acquiring big data but also as an avenue towards a more democratic research based on evidence and informed decision-making (Bonney et al., 2009; Sanz et al., 2014).

The potential of including similar approaches in archaeology and heritage management goes far beyond data collection. At the basis of sustainable cultural heritage management lies an understanding of cultural heritage as a valuable resource and a collective property (see Guttormsen \& Swensen, 2016). By enabling members of the public to interact directly with the past and by distributing stewardship of portable antiquities, we stimulate and enhance such attitudes. This should not be misunderstood as an argument in favour of private possession of archaeological finds. In our work in our respective regions, we have to acknowledge that in some countries the legal frameworks grant ownership rights over cultural property to individuals; we must therefore try to make the best of this situation through digital recording of finds data. Even with finds that must be reported and with museums having the opportunity to acquire them, the acquisition of finds is necessarily selective: in England, Wales, and Northern Ireland, for example, about 40 per cent of all Treasure finds - typically precious metal finds as well as hoards that come under the jurisdiction of the Treasure Act 1996 - are acquired by museums, though the reasons for non-acquisition vary considerably (see https://finds.org.uk/publications/).
We hold that hobbyist metal detecting and its (often) very passionate community of practitioners offer a unique opportunity to use archaeology in the active promotion of the idea of shared ownership and custody over heritage resources, even in contexts where such responsible attitudes and practices do not prevail. Though this might be overly idealistic, given the many cases of illicit detecting, we see great potential in cooperation with responsible detectorists as a pathway towards a democratic, participatory heritage management, and as a way of releasing archaeology's capacity to contribute to building inclusive and democratic societies.

\section{Problematic Aspects of a Cooperative Ap- PROACH}

It would be naive to claim that a liberal and cooperative approach to non-professional metal detecting is without challenges. As emphasized earlier, such an approach does not necessarily prevent individuals from practising illicit and/or irresponsible detecting. Neither can we claim that a recording scheme is the solution to all problems relating to hobby metal detecting (see Gill, 2010; Rasmussen, 2014). Liberal and cooperative approaches have even been said to create a demand and extra motivation for detectorists, in particular because professional validation may increase an object's value on the antiquities market (Lecroere, 2016). Some finds will always remain unreported in a context where professionals reach out to hobby detectorists, and it is open to debate whether this loss is a price worth paying for the representative fraction of finds that does get reported in areas with finds recording schemes.

The diverse and often oppositional attitudes and principles prevailing in the professional sector and the detecting communities constitute a further challenge, in part because the different values and meanings placed on the archaeological heritage often stand in the way of cooperation. Yet building bridges across such differences and forging trustful relationships is a basic condition for a cooperative and permissive approach. Although sceptical attitudes on the side of the professional sector may be well-founded in cases of illegal or irresponsible detecting, the mutual mistrust that has built up between professional archaeologists and hobby detectorists also hampers cooperation with practitioners who are willing to collaborate or at least open to the idea. 


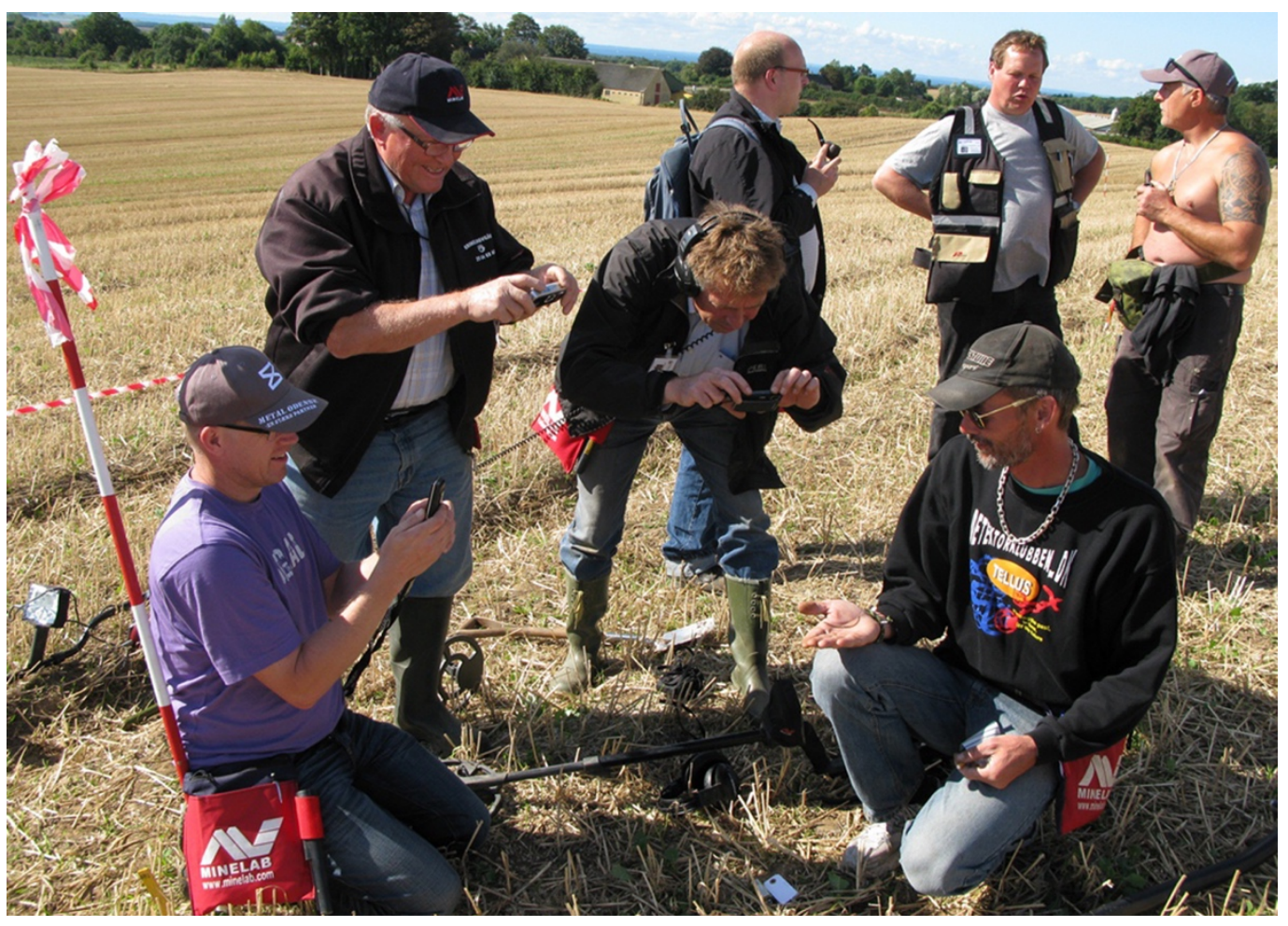

Figure 5. Typical situation at a detector survey event on discovery of a notable find, illustrating the potential of metal detecting to engage in a personal and hands-on dialogue with the past. BIFROST rally 2010 organized by the Danish detector associations Harja and Tellus in cooperation with Odense Bys Museer at Voldtofte, south-west Funen. Photograph: Allan Faurskov.

The economic sustainability of cooperative approaches poses another challenge. Their long-term implementation can put a heavy administrative and financial burden on the official heritage sector and its institutions. Making newcomers to hobby detecting aware of legal frameworks and encouraging them to adhere to good archaeological practice requires time and resources which are already limited within a notoriously underfunded sector. Moreover, basic finds recording is a costly affair, even if finders are self-recording. The cost of a permissive and cooperative model may be greater than the cost of restrictive models, at least as long as restrictions are not enforced. Again, it is open to debate whether the financial balance would still be the same if one considered the investment necessary to enforce a restrictive regime properly and actively prevent illegal detecting.

The European Public Finds Recording NetWORK'S VISION STATEMENT

There is no single solution to hobby metal detecting and we do not consider our approaches to be without challenges. All solutions need to be adapted to specific national or regional circumstances that, in many cases, may differ significantly from the contexts within which we work. In the finds-rich and less intensely cultivated regions of southern Europe, for example, with very different socio-economic conditions and attitudes towards cultural heritage, the professional sector confronts a very different reality (e.g. Marín-Aguilera, 2012, for a discussion of looting in Italy). Nonetheless, considering all the factors discussed above, we still think that archaeology and society at large are best served by cooperating with hobby metal detecting. It is on this ground that we have formulated a shared set of principles, goals, and visions that include:

- Broad public engagement and access to the archaeological heritage at local, regional, national, and European level

- A democratized approach to heritage management in Europe, stimulated through the incorporation of principles of citizen science and crowdsourcing

- A recognition of recorded public finds as an important body of archaeological evidence for human behaviour and interaction

It is our objective to work closely together, and with other areas, to: 
- Advance archaeological knowledge through the recording and research of publicly discovered finds

- Encourage best archaeological practice in the field when searching for and recording publicly discovered finds

- Support ways for public finds to be preserved and made accessible for the benefit of the whole of society, nationally and internationally

- Enable members of the public to actively contribute to the recording and handling of the archaeological heritage in the pursuit of knowledge

- Promote international cooperation in the field of archaeological finds recording

- Advance knowledge of public attitudes towards the cultural heritage and improve understanding of their impact

- Develop democratic approaches to heritage management in Europe.

We will achieve these goals by:

- Making information on archaeological finds discovered by the public accessible to all, including international researchers as well as the wider public

- Facilitating the incorporation and use of public finds in cross-national research

- Distributing knowledge on regulation and responsible behaviour for the public when searching for (and recovering), or discovering by chance, archaeological objects

- Acting as an intermediary between finders of scientifically important finds and museum and heritage professionals in a responsible way

- Exchanging information on regulations, experience, and expertise with international colleagues

- Improving standards of archaeological work undertaken by members of the public to promote a sense of shared stewardship of the past

- Supporting research through our finds recording databases and other means, by acting as intermediaries for finds experts, and by identifying gaps in archaeological small finds knowledge

- Incorporating and further developing principles of citizen science and crowdsourcing in public finds recording.

This vision statement has emerged out of the practical experience of developing and provisioning digital schemes that facilitate the recording of metal detector finds as well as an academic endeavour to better understand metal detector communities and their impact on European cultural heritage. While the first is a very practical expression of what we consider to be the cooperative approach in our vision, other elements have broader implications and are applicable in both permissive contexts and in contexts that ban or otherwise restrict metal detecting. In our view, this combination of experience and factual knowledge is a key prerequisite for the development of an appropriate response towards the metal detector phenomenon.

\section{ConcLusion}

Even within the approach we advocate here, obvious differences exist in the ways our principles and aims are applied. A consistently enforced restrictive approach to metal detecting may be the best option in certain contexts where detecting has a destructive impact on cultural heritage. In other circumstances, nuanced restrictions are not necessarily a hindrance to cooperating with practitioners who are willing to detect in a responsible manner.

We see the enormous benefits responsible metal detecting has to offer to archaeological research, to the protection of finds buried in the ploughsoil in open and cultivated landscapes, and with respect to the social role of archaeology in a changing society. A cooperative approach, in our perspective, stands as a more rewarding, less damaging, and more sustainable alternative to restrictive models. We, therefore, consider it necessary and timely to re-evaluate prohibition models and to discuss openly the various options for a more constructive response to the metal detecting hobby. We hope that our expertise and experiences in establishing and promoting public finds recording schemes in England, Wales, Denmark, Finland, Flanders and the Netherlands will inspire others exploring more cooperative approaches towards hobby metal detecting.

\section{ACKNOWLEDGEMENTS}

The authors would like to thank the anonymous peer reviewers and editorial team of the European Journal of Archaeology for their valuable feedback on earlier drafts of this article. Suzie Thomas and Anna Wessman would like to acknowledge the Academy of Finland, Decision Number 310854. 


\section{REFERENCES}

Ariadne, 2019. ARIADNEplus: Advanced Research Infrastructure for Archaeological Dataset Networking in Europe [online] [accessed 1 November 2019]. Available at:Vhttps://ariadne-infrastructure.eu/wp-content/uploads/2019/02/ARIADNEPlus synopsis-short.pdf>

Bland, R. 2005. A Pragmatic Approach to the Problem of Portable Antiquities: The Experience of England and Wales. Antiquity, 79: 440-47. https://doi.org/10.1017/S0003598X00114218

Bonney, R, Ballard, H., Jordan, R., McCallie, E., Phillips, T., Shirk, J., and Wilderman, C. C. 2009. Public Participation in Scientific Research: Defining the Field and Assessing Its Potential for Informal Science Education. A CAISE Inquiry Group Report. Washington, D.C.: Center for Advancement of Informal Science Education (CAISE). [online] [accessed 1 November 2019]. Available at: http://www.birds.cornell.edu/citscitoolkit/publications/CAISE-PPSR-report2009.pdf

Christiansen, T.T. 2019. Metal-detected Late Iron Age and Early Medieval Brooches from the Limfjord Region, Northern Jutland: Production, Use and Loss. Journal of Archaeology and Ancient History, 2: 3-41. http://uu.diva-portal.org/smash/record.jsf?pid=diva2\%3A1297079\&dswid=4103

Cooper, A. \& Green, C. 2017. Big Questions for Large, Complex Datasets: Approaching Time and Space Using Composite Object Assemblages. Internet Archaeology 45. https://doi.org/10.11141/ia.45.1

Daubney, A.J. 2016. Portable Antiquities, Palimpsests, and Persistent Places: A Multi-Period Approach to Portable Antiquities Scheme Data in Lincolnshire. Leiden: Sidestone.

Deckers, P., 2012. 'Productive Sites' in the Polders? 'Griffin Brooches' and Other Early Medieval Metal Artefacts from the Belgian Coastal Plain. Medieval and Modern Matters, 3: 21-43.

https://doi.org/10.1484/J.MMM.5.102018

Deckers, P. 2019. Archaeological Metal Detecting by Amateurs in Flanders: Legislation, Policy and Practice of a Hobby. In: S. Campbell, L. White \& S. Thomas, eds. Competing Values in Archaeological Heritage. Cham: Springer International, pp. 103-23. https://doi.org/10.1007/978-3319-94102-8_8

Deckers, P., Bleumers, L., Ruelens, S., Lemmens, B., Vanderperren, N., Marchal, C., et al. 2016. MEDEA: Crowd-Sourcing the Recording of Metal-Detected Artefacts in Flanders (Belgium). Open Archaeology, 2: 264-77. https://doi.org/10.1515/opar-2016-0019

Deckers, P., Dobat, A., Ferguson, N., Heeren, S., Lewis, M. \& Thomas, S. 2018. The Complexities of Metal Detecting Policy and Practice: A Response to Samuel Hardy, 'Quantitative Analysis of Open-Source Data on Metal Detecting for Cultural Property' (Cogent Social Sciences 3, 2017). Open Archaeology, 4: 322-33.https://doi.org/10.1515/opar-2018-0019

Dobat, A.S. 2013. Between Rescue and Research: An Evaluation after 30 Years of Liberal Metal Detecting in Archaeological Research and Heritage Practice in Denmark. European Journal of Archaeology, 16: 704-25. https://doi.org/10.1179/1461957113Y.0000000041

Dobat, A.S., Trier Christiansen, T., Jensen, P., Henriksen, M.B., Holst, M.K., Ruhe, R., et al. 2019a. The DIME Project: Background, Status and Future Perspectives of the user Driven Recording Scheme for Metal Detector Finds. Danish Journal of Archaeology, 8: 1-15. https://tidsskrift.dk/dja/article/view/111422/164712

Dobat, A.S., Wood, S.O., Jensen, B.S., Schmidt, S. \& A.S. Dobat. 2019b. 'I Now Look Forward to the Future, by Finding Things from our Past...' Exploring the Potential of Metal Detector Archaeology as a Source of Well-being and Happiness. International Journal of Heritage Studies, 25: 117. https://doi.org/10.1080/13527258.2019.1639069

Fahlander, F. 2017. The Changing Roles of Archaeology in Swedish Museums. Current Swedish Archaeology, 25: 13-19.

Faro, 2005. Council of Europe Framework Convention on the Value of Cultural Heritage for Society, Faro, 27.X.2005 (Council of Europe Treaty No. 199). [online] [accessed 1 November 2019]. Available at: https://www.coe.int/fr/web/conventions/full-list/-/conventions/rms/0900001680083746

Ferguson, N. 2013. Biting the Bullet: The Role of Hobbyist Metal Detecting within Battlefield Archaeology. Internet Archaeology, 33. https://doi.org/10.11141/ia.33.3

Ferguson, N. 2016. Lost in Translation: Discussing the Positive Contribution of Hobbyist Metal Detecting. Open Archaeology, 2: 115-26. https://doi.org/10.1515/opar-2016-0008 
Feveile, C., 2016. Understanding the Hinterland of the Ladby Ship Grave. In: V.E. Turner, O. Owen, D, Waugh \& F. Bradford., eds., Shetland and the Viking World. Papers from the Proceedings of the Seventeenth Viking Congress Lerwick. Lerwick: Shetland Heritage Publications, pp. 229-35.

Ganciu, I. 2018. Heritage for Sale! The Role of Museums in Promoting Metal Detecting and Looting in Romania. Heritage, 1: 437-52.https://doi.org/10.3390/heritage1020029

Gill, D.W.J. 2010. The Portable Antiquities Scheme and the Treasure Act: Protecting the Archaeology of England and Wales? Papers from the Institute of Archaeology, 20: 1-11.

Gundersen, J., Rasmussen, J. \& Ragnar, L. 2016. Private Metal Detecting and Archaeology in Norway. Open Archaeology, 2: 160-70. https://doi.org/10.1515/opar-2016-0012

Günther, G. 2019. Sieht nach Volltreffer aus. Chrismon, January 2019 (1): 34-40. [online] [accessed 4 Oktober 2019]. Available at: https://chrismon.evangelisch.de/artikel/2018/42247/kriegsgraeber-gefallene-weltkriegssoldaten-estland

Guttormsen, T.S. \& Swensen, G., eds. 2016. Heritage, Democracy and the Public: Nordic Approaches. Farnham: Ashgate.

Hadley, D.M. \& Richards, J.D. 2018. In Search of the Viking Great Army: Beyond the Winter Camps. Medieval Settlement Research, 33: 1-17. https://doi.org/10.5284/1017430

Haldenby, D. \& Richards, J.D. 2010. Charting the Effects of Plough Damage Using Metal-Detected Assemblages. Antiquity, 84: 1151-62. https://doi.org/10.1017/S0003598X00067144

Hardy, S.A. 2017. Quantitative Analysis of Open-Source Data on Metal Detecting for Cultural Property: Estimation of the Scale and Intensity of Metal Detecting and the Quantity of Metal-Detected Cultural Goods. Cogent Social Sciences, 3: 1298397. https://doi.org/10.1080/23311886.2017.1298397

Heeren, S. \& van der Feijst L. 2017. Prehistorische, Romeinse en middeleeuwse fibulae uit de Lage Landen. Beschrijving, analyse en interpretatie van een archeologische vondstcategorie. Amersfoort: Eigen Beheer.

Holtorf, C. 2005. From Stonehenge to Las Vegas. Archaeology as Popular Culture. Walnut Creek (CA): AltaMira.

Huth, C. 2013. Vom rechten Umgang mit Sondengängern: Das 'Portable Antiquities Scheme' in England und Wales und seine Folgen. Archäologische Informationen, 36: 129-37. https://doi.org/10.11588/ai.2013.0.15327

Immonen, V. \& Kinnunen, J. 2017. 'Quidditching' and the Emergence of New Heritage Identities Amateur Metal Detecting in Finland. Public Archaeology, 15: 163-85. https://doi.org/10.1080/14655187.2017.1352188

Jeppesen, J. 2011. Randlev. In: J. Varberg \& H. Skov, eds. Aros og vikingernes verden: syv vikingers fortællinger og rejseberetninger fra Aros. Højbjerg: Moesgård Museum, pp. 34-38.

Jørgensen, L. 2000. Storgården ved Tissø. Tolkning af aktivitetsområder og anlæg på grundlag af detektorfundene fra pløjelaget. In: M.B. Henriksen, ed. Detektorfund: hvad skal vi med dem? Dokumentation og registrering af bopladser med detektorfund fra jernalder og middelalder (Skrifter fra Odense Bys Museer 5). Odense: Odense Bys Museer, pp. 27-43.

Kajda K., Marx A., Wright H., Richards J., Marciniak A., Rossenbach K.S., et al. 2018. Archaeology, Heritage, and Social Value: Public Perspectives on European Archaeology. European Journal of Archaeology, 21: 96-117. https://doi.org/10.1017/eaa.2017.19

Karl, R. \& Möller, K. 2016. Empirische Untersuchung des Verhältnisses der Anzahl von Metallsucher/Innen im Deutsch-Britischen Vergleich. Oder: Wie wenig Einfluss die Gesetzeslage hat. Archäologische Informationen, 39: 215-26. https://doi.org/10.11588/ai.2016.1.33553

Kars, M. \& Heeren, S. 2018. Archaeological Small Finds Recording in the Netherlands: The Framework and Some Preliminary Results of the Project Portable Antiquities of the Netherlands (PAN). Medieval Settlement Research, 33: 21-30. https://doi.org/10.5284/1017430

Komoróczy, B., Vlach, M. \& Zelíková M. 2017. Dokumentace, publikace a interpretace detektorových nálezů na př́kladu spon typu Jobst 4F 31. In: E. Droberjar \& B. Komoróczy, eds. Římské a germánské spony ve střední Evropě. Brno: Archeologický ústav AV ČR, pp. 31-64.

Lecroere, T. 2016. 'There Is None So Blind as Those Who Won't See': Metal Detecting and Archaeology in France. Open Archaeology, 2: 182-93. https://doi.org/10.1515/opar-2016-0014

Lewis, M. 2016. A Detectorist's Utopia? Archaeology and Metal-Detecting in England and Wales. Open Archaeology, 2: 127-39. https://doi.org/10.1515/opar-2016-0009

Lewis, M., ed. 2018. The Portable Antiquities Scheme Annual Report 2017. London: The British Museum. [online] [accessed 16 December 2019]. Available at: https://finds.org.uk/documents/annualreports/2017.pdf 
Majchczack B.S.M. 2016. The Current Model of Archaeological Metal Detecting and its Success in Schleswig-Holstein. In: J. Martens \& M. Ravn, eds. Pløyejord som kontekst. Nye utfordringer for forskning, forvaltning og formidling. Kristiansand: Kulturhistorisk museum \& Universitetet i Oslo, pp. 89-100.

Makowska, A., Oniszczuk, A. \& Sabaciński, M. 2016. Some Remarks on the Stormy Relationship Between the Detectorists and Archaeological Heritage in Poland. Open Archaeology, 2: 171-81. https://doi.org/10.1515/opar-2016-0013

Marín-Aguilera, B. 2012. Italy: A Huge Open-air Museum: 'Tombaroli' at Cerveteri and Tarquinia. In: A. Castillo, ed. Proceedings of the First International Conference on Best Practices in World Heritage: Archaeology. Madrid: Universidad Complutense de Madrid, pp. 563-79.

Meller, H., ed. 2004. Der geschmiedete Himmel. Die weite Welt im Herzen Europas vor 3600 Jahren. Stuttgart: Theiss.

Nord, A.G. \& Lagerlöf, A. 2002. Påverkan på arkeologiskt material i jord: Redovisning av två forskningsprojekt. Stockholm: Riksantikvarieämbetet. http://samla.raa.se/xmlui/bitstream/handle/raa/69/9172092823.pdf?sequence=1\&isAllowed=y

Oksanen, E. \& Lewis, M. 2015. Medieval Markets and Portable Antiquities Scheme. Medieval Settlement Research, 30: 54-59.

Patiwael, P.R., Groote, P. \& Vanclay, F. 2019. Improving Heritage Impact Assessment: An Analytical Critique of the ICOMOS Guidelines. International Journal of Heritage Studies, 25: 333-47. https://doi.org/10.1080/13527258.2018.1477057

Perring, D. \& Orange, H. 2017. Commercial Archaeology in the UK: Public Interest, Benefit and Engagement. In: G. Moshenska, ed. Key Concepts in Public Archaeology. London: UCL Press, pp. 138-50.

Perry, S. 2019. The Enchantment of the Archaeological Record. European Journal of Archaeology, 22(3): 354-71. https://doi:10.1017/eaa.2019.24

Perry, S. \& Beale, N. 2015. The Social Web and Archaeology's Restructuring: Impact, Exploitation, Disciplinary Change. Open Archaeology, 1(1). [online] [accessed 16 December 2019] doi:10.1515/opar-2015-0009

Petersen, P. V. 1994. Excavations at Sites of Treasure Trove at Gudme. In: P.O. Nielsen, K. Randsborg \& H. Thrane, eds. Archaeology of Gudme and Lundeborg (Arkaeologiske studier 10). Copenhagen: Akademisk forlag, pp. 30-40.

Portable Antiquities Advisory Group. 2017. Code of Practice for Responsible Metal Detecting in England \& Wales (2017 Revision). London: PAAG. [online] [accessed 16 December 2019]. Available at: https://finds.org.uk/documents/file/Code-2017.pdf

Portable Antiquities of the Netherlands. 2019. Gedragscode en regels voor verantwoord gebruik van de metaaldetector in Nederland. Amsterdam: Vrije Universiteit Amsterdam \& Amersfoort: Rijksdienst voor het Cultureel Erfgoed. [online] [accessed 16 December 2019]. Available at: https://portable-antiquities.nl/pan/resources/downloads/NL-2-Brochure regelgeving Metaaldetectie mei 2019 LR.pdf

Rácz, T.A. 2017. Metal-detector Users Affiliated to Museums. Building a Model of Community Archaeology in Pest County. Hungarian Archaeology Autumn 2017. http://www.hungarianarchaeology.hu/?page id=3661\#post-7346

Rasmussen, J.M. 2014. Securing Cultural Heritage Objects and Fencing Stolen Goods? A Case Study on Museums and Metal Detecting in Norway. Norwegian Archaeological Review, 47: 83--07. https://doi.org/10.1080/00293652.2014.899616

Robbins, K.J. 2013. Balancing the Scales: Exploring the Variable Effects of Collection Bias on Data Collected by the Portable Antiquities Scheme. Landscapes, 14: 54-72. https://doi.org/10.1179/1466203513Z.0000000006

Rodríguez Temiño, I. \& Roma Valdés, A. 2015. Fighting against the Archaeological Looting and the Illicit Trade of Antiquities in Spain. International Journal of Cultural Property, 22: 111-30. https://doi.org/10.1017/S094073911500003X

Serrano Sanz, Fermin, Teresa Holocher-Ertl, Barbara Kieslinger, Francisco Sanz Garcia und Candida G. Silva (2014): White Paper on Citizen Science in Europe. Socientize Consortium/European Commission. [online] [accessed 1 November 2019]. Available at: http://www.zsi.at/object/project/2340/attach/White Paper-Final-Print.pdf

Scheschkewitz, J. 2013. Merely Searching for Treasures or Valid Interest in Cultural History? Various Motivations in Germany. In: A. Lagerlöf, ed. Who Cares? Perspectives on Public Awareness, Participation and Protection in Archaeological Heritage Management (EAC Occasional Paper, 8). Namur: Jambes, pp. 53-59. 
Stebbins, R.A. 1992. Amateurs, Professionals, and Serious Leisure. Montréal: McGill-Queen's University Press.

Svensson, H. 2014. Uppdragsarkeologin och kulturmiljölagen hotar fornsakerna - svar till Raä. Fornvännen, 109: 139-44. [online] [accessed 16 December 2019]. Available at: http://kulturarvsdata.se/raa/fornvannen/html/2014_139

Thomas, S. 2012. Searching for Answers: A Survey of Metal-Detector Users in the UK. International Journal of Heritage Studies, 18: 49-64. https://doi.org/10.1080/13527258.2011.590817

Thomas, S. 2016. The Future of Studying Hobbyist Metal Detecting in Europe: A Call for a Transnational Approach. Open Archaeology, 2: 140-49. https://doi.org/10.1515/opar-2016-0010

Thomas, S., Wessman, A., Siltainsuu, J. \& Perttola, W. 2015. Understanding Metal Detecting and Archaeology in Finland. Cuadernos de Prehistoria y Arquelogia de la Universidad de Granada, 25: 185-97.

Tronner, K., Nord, A.G. \& Borg, G.C. 1995. Corrosion of Archaeological Bronze Artefacts in Acidic Soil. Water, Air, and Soil Pollution, 85: 2725-30. https://doi.org/10.1007/BF01186246

UN, 2019. The Universal Declaration of Human Rights. [online] [accessed 1 November 2019]. Available at: https://www.ohchr.org/EN/UDHR/Documents/UDHR_Translations/eng.pdf

Ulst, I. 2010. The Problems of 'Black Archaeology' in Estonia. Estonian Journal of Archaeology, 14: 153-69. https://doi.org/10.3176/arch.2010.2.04

Valletta 1992. European Convention on the Protection of the Archaeological Heritage, Valletta, 16.I.1992 (Council of Europe Treaty No.143) [online] [accessed 1 November 2019]. Available at: https://www.coe.int/en/web/conventions/full-list/-/conventions/rms/090000168007bd25

Wessman, A. forthcoming. Searching for the Past: Metal Detecting and its Impact on Cultural Heritage in Finland. In: M. Bintley, J. Hines, A. Richardson, A. Seaman \& E. Swift, eds. Lands and Seas: Post-Roman Transitions and Relations across the Channel, North Sea and Baltic Worlds (Neue Studien Zur Sachsenforschung, 10). Stuttgart: Theiss.

Wessman, A., Thomas, S., Rohiola, V., Koho, M., Ikkala, E., Tuominen, J., et al. 2019. Citizen Science in Archaeology: Developing a Collaborative Web Service for Archaeological Finds in Finland. In: J.H. Jameson \& S. Musteață, eds. Transforming Heritage Practice in the 21st Century, Contributions from Community Archaeology (One World Archaeology). Cham: Springer, pp. 337-52.

Winkley, F. 2016. The Phenomenology of Metal Detecting: Insights from a Unique Type of Landscape Experience. Papers from the Institute of Archaeology, 25: Art. 13. https://doi.org/10.5334/pia.496

Worrell, S., Egan, G., Naylor, J., Leahy, K. \& Lewis, M., eds. 2010. A Decade of Discovery: Proceedings of the Portable Antiquities Scheme Conference 2007 (British Archaeological Reports British Series 520). Oxford: Archaeopress. 